\title{
ISLAMIC PARTY AND PLURALISM \\ The View and Attitude of Masyumi towards Pluralism in Politics (1945-1960)
}

\section{Firman Noor}

Centre for Political Studies, Indonesian Institute of Sciences (LIPI) Jakarta, Indonesia

email:firman.noor@yahoo.co.id

\section{Abstract}

This article discusses Masyumi's response towards pluralism, particularly about the political diversity in the first fifteen years of Indonesia independent era. As the largest Islamic party in Indonesian history, Masyumi was well known by many as the champion of democracy and one of the essential elements in the nationalist movement. However, regarding pluralism, for some, Masyumi positive attitude on this matter has been doubtful, regarding this party as the guru of intolerance for some contemporary Islamic organisations. By exploring the ideals and practical aspects of this party, this article wants to show the nature of Masyumi's view and attitude in answering political diversity that in the long run indicates the real position of this party in pluralism in politics. The discussion indicates that despite some weaknesses in undergoing the spirit of honouring diversity, in particular when dealing with the communists, Masyumi, in general, hadproven its position as one of the essential elements in Indonesian political history that in many ways eager to develop and maintain the spirit of pluralism.

[Tulisan ini mendiskusikan peribal respons Masyumi terbadap pluralisme, khususnya terkait dengan politik keragaman dalam rentang limabelas tabun setelah Indonesia merdeka. Sebagai partai Islam terbesar dalam sejarah Indonesia, Masyumi dikenal luas sebagai terdepan dalam praktik. 
demokrasi dan pemain penting dalam gerakan nasionalisme. Meskipun demikian, bagi sebagian orang, respons positif Masyumi terhadap isu pluralisme tetap diragukan mengingat partai ini dianggap sebagai model intoleransi bagi organisasi Islam dewasa ini. Tulisan ini ingin menunjukkan bahwa pandangan dan sikap Masyumi dalam menjawab keragaman politik. mengindikasikan posisinya yang jelas dalam pluralisme politik. Walaupun ada dukungan lemah terhadap semangat keragaman, kbususnya terkait dengan kelompok komunis, secara umum Masyumi membuktikan dirinya sebagai elemen penting dalam sejarah politik. Indonesia dengan berbagai cara dalam membangun dan mempertahankan semangat pluralisme.]

Keywords: Masyumi, Islam politic, democracy, diversity, pluralism

\section{A. Introduction}

Indonesia is a plural country in many aspects. It is plural not only in the primordial context but also in the context of social and political life. The presence of many political parties with different ideological principles, in particular during the first fifteen years after the independence day, signified the pluralism in politics. In this kind of political situation, the positive spirit of pluralism becomes a necessity. Islamic communities, however, which occupy the larger part of Indonesian people, react differently towards pluralism. Many groups tend to become proponents of pluralism, believing that Islamic teachings at heart welcome pluralism. Some others, on the other hand, are half-hearted supporters to this concept, by regarding the important roles of Islamic communities for the nations and society, particularly in the past, as the reason for leading position of them in this country.

Concerning those various responses, a study aiming to expand people understanding on Islamic communities' response to Indonesia's pluralism, in particular on Islamic communities' response to political diversity in early years of the independent era is an interesting one. It would provide a more profound picture on Indonesian Muslim response to the idea of pluralism in general and particularly on diversity in political life. In this regards, one of the iconic groups that could be regarded as Muslim representation back in those days was Partai Politik Islam Indonesia Masyumi (Masyumi). Masyumi, established in November 1945 
in Yogyakarta following the national meeting of Kongres Umat Islam (the Congress of Islamic Communities), was the most popular Islamic party after the fall of Dutch Colonial Government in Indonesia until its dissolution in $1960 .^{1}$

Its members were estimated around ten million people, which made Masyumi at that time the largest Islamic party in Indonesia, even in the world. ${ }^{2}$ In the 1955 Election, Masyumi secured 57 seats in parliament, the similar number of seat gained by the Indonesian Nationalist Party (PNI) the Indonesia largest party regarding the number of voters. Moreover, many people believe that Masyumi was one of the patriotic parties in Indonesia. ${ }^{3}$ On the other hand, this party also was popularly known as the bastion of democracy. However, regarding pluralism, the position of Masyumi for this matter is still contentious.

Some studies categorised this party, and its followers, as an institution that direct or indirectly initiated the presence of intolerant Islamic faction, conveyed hatred or anxiety spirit to non-Muslims, ${ }^{4}$ including Islamic radical groups in the contemporary Indonesia. ${ }^{5}$ Some people even called this party as radical, or fundamentalist group. ${ }^{6}$ Some

${ }^{1}$ Masyumi claimed that at least up to 31 December 1950, its members were around ten million peoples, see. Departemen Penerangan Republik Indonesia, Kepartaian di Indonesia (Jakarta, 1951), p. 14. According to Charles Wolf, Masyumi's member had overlapped other parties' members; Charles Wolf, Charles Wolf, The Indonesian Story; the Birth, Growth and Structure of the Indonesian Republic (New York: Institute of Pacific Relations, 1949), p. 57.

${ }^{2}$ Rémy Madinier, Partai Masjumi: Antara Godaan Demokrasi \& Islam Integral (Bandung: Mizan, 2013), p. 1.

${ }^{3}$ Mohammad Natsir, for instance, the Masyumi Chairman from 1950-1958, who was granted National Hero by the Indonesian Government in 2008, was labelled as one of the Indonesia's nationalist giants; George McTurnan Kahin, "In Memoriam: Mohammad Natsir (1907 -- 1993)”, Indonesia, vol. 56 (1993), p. 158; “"Bung Natsir adalah Pejuang Besar"', Media Dakwah, vol. 25 (1993), pp. 21-3; Amir Hamzah Wiryosukarto (ed.), Wawasan Politik Seorang Muslim Patriot: Kumpulan Karangan (Jakarta: YP2LPM (Yayasan Pusat Pengkajian, Latihan, dan Pengembangan Masyarakat), 1984).

${ }^{4}$ Madinier, Partai Masjumi, p. 411.

${ }^{5}$ Martin van Bruinessen, "Genealogies of Islamic Radicalism in Post-Suharto Indonesia”, South East Asia Research, vol. 10, no. 2 (2002), pp. 117-54.

${ }^{6}$ See for instance, Zakaria J. Ngelow, "Interfaith Cooperation against Radicalism and Violence in Indonesia: A Christian Perspective", CTC Bulletin, vol. XXIV, no. 3 (2008). It also can be traced from the question of people who regards Masyumi as a radical party, see such a question in the "Interview with Ahmad Syafii Maarif", Asian 
people also regarded Masyumi as being insensitive and less committed to respecting other Islamic groups' beliefs or traditions. ${ }^{7}$ However, some people believed that this party was a pluralism devotee. Jacob Oetama, the Catholic figure and the founder of daily newspaper Kompas, for instance, acknowledges that Masyumi was an excellent example of pluralism defender. Oetama reckoned Masyumi as a "modern Islamic party that acknowledged Indonesia pluralism as its characteristic which was continued by K.H Abdurrahman Wahid, among others".

According to the above conditions, this article would discuss the very nature of Masyumi's responses toward pluralism. Some relevant studies on this party have been conducted by scholars. Their studies had successfully covered up many important aspects of this party. ${ }^{9}$ However, an in-depth study related to Masyumi's attitudes towards pluralism is still rare. This study, hence, is also expected to provide more insight on Masyumi and fill the space that left by previous studies.

This article will explore on how the Masyumi reacted towards pluralism, in particular pluralism in politics? How far Masyumi's pluralism, reflected mainly by the view and attitudes, is in line with the very basic principles of pluralism? For this aim, this article would discuss two most important aspects, which each element consists of several issues. The first is the normative aspect or thinking, which includes the discussions on (1) ideal state and (2) pluralism as a historical object or fact for the Indonesian state.

The second is practical aspects or attitudes, comprised of four

Christian Review, vol. 2, nos. $2 \& 3$ (2008), p. 8.

${ }^{7}$ Remy Madinier and Andre Feillard, "At the Sources of Indonesian Political Islam's Failure: The Split between the Nahdlatul Ulama and the Masyumi in Retrospect", Studia Islamika, vol. 6, no. 2 (2014), pp. 7-9, 11-4.

${ }^{8}$ Jakob Oetama, "“Catatan Penutup: Paradoks Existential Prawoto Mangkusasmito"”, in Alam Pikiran dan Jejak Perjuangan Prawoto Mangkusasmito: Ketua Umum (Terakhir) Partai Masyumi, ed. by S.U. Bajasut and Lukman (Jakarta: Penerbit Buku Kompas, 2014), p. 545.

9 Among these important studies are Deliar Noer, Partai Islam di Pentas Nasional: Kisah dan Analisis Perkembangan Politik Indonesia 1945-1965 (Bandung: Mizan, 2000); Yusril Ihza Mahendra, Modernisme dan Fundamentalisme dalam Politik Islam: Perbandingan Partai Masyumi (Indonesia) dan Partai Jama'at-i-Islami (Pakistan) (Jakarta: Paramadina, 1999); Greg Fealy and Bernhard Platzdasch, "The Masyumi Legacy: Between Islamist Idealism and Political Exigency”, Studia Islamika, vol. 12, no. 1 (2005), pp. 73-99. 
main discussions namely: (1) the attitude towards the political diversity in the Islamic communities internal context; (2) the attitude towards the non-Muslims (Catholics and Protestants) political groups; (3) the attitude towards the secular groups, including the nationalists, socialist and communists; (4) the general characteristic of Masyumi programs, which one of them was related to Guided Democracy concept proposed by President Soekarno.

For those purposes, this article applies desk research by exploring relevant documents related to the subject of the study. Many of important and original documents were mainly found in the former Head Quarter of Masyumi in Jakarta, which today is occupied by the Dewan Da'wah Islamiyah Indonesia (Indonesian Board of Islamic Proselytizing/DDII) organisation established by Mohammad Natsir and some of his former Masyumi colleagues. At this place, the writer also had the opportunity to explore very rare documents, including some classic documents in the private collection of Natsir, for instance, volumes of the Badan Konstituante meetings records during the 1950s, volumes of Hikmah Magazine (the most salient Masyumi magazine, that was used as one of the important Masyumi political communication media), classified writings, proceedings for limited group only (particularly for internal Masyumi members), unpublished articles or documents related to Masyumi's political positions and agendas; and several master theses and doctoral dissertations by invitation universities across the nation.

Also in the DDII's library, the writer found important old and new books, which are mainly about the deeds of the salient figures of Masyumi, in particular, the elites and general chairpersons of the party. As part of the research activity, the writer also took an opportunity to visit leading institutions in dealing with old documents and archives storing. They include the Perpustakaan Nasional (National Library) and the Arsip Nasional Republik Indonesia (National Archives of the Republic of Indonesia) both are located in Jakarta to gain some very important information and insights through exclusive documents, manuscripts and photographs mainly on the Masyumi and its important figures' activities.

The research was also conducted in the Perpustakaan Pusat Universitas Indonesia (Central Library of University of Indonesia) in Depok, West Java and the Pusat Dokumentasi dan Informasi Ilmiah-Lembaga Ilmu Pengetabuan 
Indonesia (Centre for Scientific Documents and Information-Indonesian Institute of Sciences/PDII-LIPI) in Jakarta, where the writer could access many interesting periodical articles, theses (of bachelor and master level) and dissertations, discussing Masyumi in many aspects. In the UK, the SOAS Library collections under the subject of Indonesian politics during the Liberal Democracy era and on the Masyumi had also helped the writer to establish imperative points of view on Masyumi. Some colleagues in Indonesia (LIPI) and UK (Oxford University) also kind-heartedly gave assistances by providing personal collections of files, manuscripts and documents, as well as discussing Masyumi from several angles and perspectives. Their opinions also provided some important and significant insights for this article.

\section{B. Pluralism in Politics}

The concept pluralism has many understandings and definitions. One of the essences of this concept is a system of thought or an acknowledgement of diversity in a community or entity related to primordial, belief, thought, social costumes, religious, inclinations, political backgrounds or tendencies on methods or mechanism differences to response things or generally in multidimensional aspect. ${ }^{10}$ This acknowledgment should not merely on the matter of realizing differences among groups or simply have awareness that "we are indeed different", but also should be in the sense of willing to provide sufficient and consequential access to whole of people, so that the differences could be well maintained and each of group characteristic could grow as it should be. In other words, it should reach a condition in which people consent to bind each other above their differences. ${ }^{11}$

Pluralism is also not only related to eagerness to reject fanaticism or extremism, but also the enthusiasm to spread out tolerance to the society and the state. This attitude would potentially sustain to the more equal

${ }^{10}$ William E. Connolly, Pluralism (Durham: Duke University Press, 2005); James A.H. Murray, William Little, and C.T. Onions, The Shorter Oxford English Dictionary on Historical Principles (Oxford: Clarendon Press, 1964), p. 1528; Kathy Rooney, Encarta Concise English Dictionary (Sydney, N.S.W.: Pan Macmillan Australia, 2001), p. 1118.

${ }^{11}$ Nurcholis Madjid, "Masyarakat Madani dan Investasi Demokrasi: Tantangan dan Kemungkinan”, Republika (10 Aug 1999). 
life establishment, ${ }^{12}$ in which every group of people would support each other in setting up mutual symbiosis among them. In short, as Giddens says, the present of mutual co-existence among different ethnic groups. ${ }^{13}$ Pluralism in this article is not an attitude that aims at synthesizing groups' uniqueness into a new-monolithic character or becoming relative ${ }^{14}$ or in other words, obliterating the boundaries between people with different background. Rather, pluralism existence should preserve the uniqueness or diversity of the people. ${ }^{15}$ According to Legenhausen "the key of tolerance is not the removal or relativisation of disagreement, but the willingness to accept genuine disagreement". ${ }^{16}$

This article focused on the pluralism in politics, which comprises of four points. The first is a viewpoint that acknowledges the diversity in beliefs, visions, objectives, understandings and strategies in politics that was adhered by different political groups, including political parties. Such differences have a connection to different primordial backgrounds, ideologies, traditions, tendencies and methods, implemented by people in dealing with political life. The second is the eagerness to perform powersharing with other political groups or distribution of power. It means they value democracy in the sense that state constitution should provide significant room for political diversity to develop and share the best they have. This attitude is clearly an opposition to centralised power run by limited people. ${ }^{17}$ According to Duverger, in a plural regime, political struggle is transparent and conducted openly, freely and without forcing people, mediated throughout political channels including political parties. ${ }^{18}$ However, pluralism in this article is not related to the idea of opposing

${ }^{12}$ Nurcholish Majid, "Ikatan Keadaban", in Cendekiawan dan Religiusitas Masyarakat (Jakarta: Tabloid Tekad dan Penerbit Paramadina, 1999), p. 72.

${ }^{13}$ Anthony Giddens, Sociology (Cambridge: Polity Press, 1993), pp. 271, 737.

${ }^{14}$ Connolly, Pluralism, pp. 38-67; William L. Rowe, Philosophy of Religion: An Introduction, 4th edition (California: Wadsworth Cengage Learning, 2007), pp. 184-8.

${ }^{15}$ Anis Malik Thoha, Tren Pluralisme Agama: Tinjanan Kritis (Jakarta: Perspektif, 2005), p. 12.

${ }^{16}$ Muhammad Legenhausen, "Misgiving about the Religious Pluralisms of Seyyed Hossein Nasr and John Hick", al-Tawbid, vol. 14, no. 3 (1997), p. 120.

${ }^{17}$ Roger Scruton, A Dictionary of Political Thought (London: Pan Book, 1983), p. 357.

${ }^{18}$ Maurice Duverger and Robert Wagoner, The Study of Politics (London: Nelson, 1972), p. 83. 
state sovereignty nor creating a "neutral state". ${ }^{19}$

The third, pluralism also means the willingness to build tolerance and compromise towards political divergences. This includes the eagerness to provide opportunities to other people with different political backgrounds or affiliations to develop their existence based on their beliefs and give a chance to participate in the decision-making process and hold strategic political positions. The fourth, pluralism in politics also means the will to have mutual co-existence fairly and equally with other political groups that live in the same political entity, by maintaining rights to life for all people. In other words, it regards the diversity as a medium to establish a mutual relationship to build better situation for all.

\section{Attitudes toward Pluralism in Politics}

Positive attitudes towards pluralism might be caused by various reasons. It could happen when the interest to hold idealism and bring about pragmatic interests collides. On the other hands, it could appear as a consequence of ideological motives, or simply to be more acceptable before the public's eyes so that the political ambitions could be easily maintained.

Masyumi came into being in a circumstance that was dominated by political schism or sectarianism based on ideological differences. Feith and Castle's study on Indonesia political thinking (1945-1965), ${ }^{20}$ for instance, has depicted such a situation. They regard that in the early period of Indonesia's independence up until 1965, there were some influential political mainstreams operated in national politics namely, Islamic modernism, Islamic Traditionalism, Radical Nationalism, Socialism and Communism. There were also other insignificant camps, including Javanism, and Christianity (Protestantism and Catholicism).

Those ideologies attracted many people and inspired their followers to establish political parties, onderbouns or social organisations, and above all influence Indonesia political situation eventually. In this situation, political contestations between political ideology believers became

${ }^{19}$ M.L.J. Wissenburg, Political Pluralism and the State: Beyond Sovereignty (New York: Routledge, 2009).

${ }^{20}$ Herbert Feith and Lance Castles (eds.), Indonesian Political Thinking, 1945-1965 (Ithaca: Cornell University Press, 1970). 
inevitable. The tendencies of competition, whether in the context of discourse or actions, based on their belief occurred almost in a daily basis. Some Indonesia observers indicate that ideology has become a very foundation for parties to response political development and to carry out political agendas, which heavy contestation among parties appears as obvious consequences. ${ }^{21}$

On the other hand, to gain more positive images from the people or have a better position in the political constellation, parties implemented some ideological adjustments. These attempts were mainly to soften their political outlook so that they could give way to the establishment of more open-minded or friendly attitudes and policies, which in the end would bring a sense of moderation. However, people sometimes reckon this situation as a merely political strategy's effect, which conceals the real agendas behind that sense. They conclude that the existing characters of a party will soon appear after it could successfully take over the power. This applies to the many fundamentalist parties that at the outset accept moderate ways before eventually comes to the radical propensity after effectively securing the power. ${ }^{22}$ In other words, the moderate attitudes, including accepting pluralism, were nothing but political guise. As for Masyumi, Madinier's work suggests that after failing to bring about Indonesia as an Islamic state, this party commences showing its real character, by performing more exclusiveness and radical gestures.

However, the intention to defend pluralism could also be ideological, in a sense that it is guided by some ideal norms more than just political interests. The next discussion would indicate whether Masyumi tends to be ambiguous or consistent in conducting pluralism? Also to explain whether its attitude was derived by political interest or ideological motives, or both? Above all, the discussion will describe the real opinions and attitudes of this party towards pluralism. The discussion would be

${ }^{21}$ Ibid., pp. 6-10; Josef A. Mestenhauser, "Ideologies in Conflict in Indonesia, 1945-1955.”, PhD Dissertation (Minnesota: University of Minnesota, 1960).

${ }^{22}$ Daniel Brumberg, "Rhetoric and Strategy, Islamic Movements and Democracy in the Middle East", in The Islamism Debate, ed. by Martin S. Kramer, Daniel Brumberg, and Merkaz Dayan le-ḥeḳer ha-Mizrah ha-Tikhon ỵe-Afriḳah (Universițat Tel-Aviv) (Tel Aviv, Israel: Moshe Dayan Center for Middle Eastern and African Studies, 1997), pp. 22-30; Ignacio Sanchez-Cuenca, "Party Moderation and Politicians' Ideological Rigidity”, Party Politics, vol. 10, no. 3 (2004), pp. 325-42. 
started by the explanation on Masyumi's point of view towards the ideal state and Indonesia pluralism.

\section{Masyumi's Points of View on the Ideal State and Pluralism}

Masyumi was the ideological party, which was moved by the interest of spreading Islamic values and laws towards society and state. In some aspects, Masyumi's understanding on pluralism found the foundation on its understanding of the ideal state and human relationship in Islam. This section would discuss some main principles in Masyumi's points of view which are related to the ideal state and pluralism that explains its tendency towards pluralism in politics.

\section{The View on the Ideal State}

The ideal state according to Masyumi was the state that stood above Islamic norms and laws. This inferred that Islam would be in favour to become the main reference or guidance for the constitution. This thought was derived from the belief that Islam had summoned every Muslims to implement Islamic teachings, including Islamic Syariah, as a foundation for the development of the state and society. ${ }^{23}$ For this reason, to implement Islamic teachings and laws in the life of individuals, society and the state was the main object for Masyumi. ${ }^{24}$ By having this objective, it did not mean that Masyumi would turn Indonesia to be a trans-national state (khilafah) or be part of it. Instead, Masyumi believed in a nation-state, comprises of diverse peoples from Sabang (Sumatera) to Merauke (Papua). ${ }^{25}$

Furthermore, Masyumi also believed that the ideal states should be the one that was conducted by the spirit rule of law and implementing

23 “Tafsir Asas", in Pedoman Perdjuangan Masjumi, 2 $2^{\text {nd }}$ ed. (Djakarta: Pimpinan Partai Masjumi, Bagian Keuangan, 1955), p. 54; M. Natsir, Islam Sebagai Dasar Negara (Jakarta: Dewan Da’wah Islamiyah Indonesia, 2000).

24 "Anggaran Dasar Partai Politik Islam Indonesia Masyumi, Article III", in Pedoman Perdjuangan Masjumi, 2 ${ }^{\text {nd }}$ ed. (Djakarta: Pimpinan Partai Masjumi, Bagian Keuangan, 1955), p. 6.

${ }^{25}$ M. Natsir, Tjita-Tjita Masjumi, Pidato Mohammad Natsir dalam Peringatan Ulang Tabun ke-X Masjumi di Jakarta 1955 (Jakarta: KAPU Masjumi Djakarta Raya), p. 3. 
republicanism based on the spirit of democratic principles. ${ }^{26}$ In this regards, every citizen had right to struggle for their interests throughout democratic ways. The ideal state, hence, was also the one that works for the whole people regardless their primordial backgrounds. It is mentioned in Tafsir Asas that the ideal state for Masyumi was the state "in which all the people from many different status could live based on the spirit of diversity". ${ }^{27}$

In line with this spirit, Masyumi also believed in the importance of tolerance for a plural country like Indonesia. Anwar Harjono, one of the important young figures of Masyumi, stated that Masyumi wanted to establish Indonesian society as a tolerant society in terms of religion, culture and politics. ${ }^{28}$ Hence, in an Islamic based state, according to this party, the freedom of religion was guaranteed and protected. ${ }^{29}$ The nonMuslims could freely carry out their religion ${ }^{30}$ and even establish political parties based on their belief as part of political rights. ${ }^{31}$ Every citizen was eligible to hold any political or governmental position, ${ }^{32}$ except for the position of president and vice president, in which only a Muslim should be entitled to those positions. ${ }^{33}$ The previous thought, however, tends to limit non-Muslim to hold those important positions. Even though, in many democratic countries, the opportunity for people from minor religious groups to hold very strategic political positions is scarcely rare. The constitution of those countries generally does not clearly state the special treatments for the majority. In this case, the implementation of the principle of proportionality seems very strict in Masyumi, and to

26 "Program Perdjuangan Masjumi", in Pedoman Perdjuangan Masjumi, 2n $\mathrm{ed}$. (Djakarta: Pimpinan Partai Masjumi, Bagian Keuangan, 1955), p. 60. Also the Konstitusi Masjumi mentioned that "The will of the people should be the foundation of the state, carried out by the government together with the People Representative Board and/or Local Board through the spirit of deliberation"; Konstitusi Masjumi, Hasil Penyelidikan Panitia Kerja, Article 11 Verse 1.

27 "Tafsir Asas", p. 46.

${ }^{28}$ Lukman Hakiem, Perjalanan Mencari Keadilan dan Persatuan: Biografi Dr. Anwar Harjono, S.H. (Jakarta: Media Da'wah, 1993), p. 348.

29 "Program Perdjuangan Masjumi", p. 60.

${ }^{30}$ Konstitusi Masjumi, Hasil Penyelidikan Panitia Kerja Article 49 Verse 3.

31 "Tafsir Asas", p. 46.

${ }^{32}$ Konstitusi Masjumi, Hasil Penyelidikan Panitia Kerja Article 41 Verse 1-2.

${ }^{33}$ Ibid. Article 49 Verse 3. 
some extent, alleviated the sense of pluralism.

Additionally, Masyumi agreed that the state should protect the human rights in any cases. ${ }^{34}$ In the Konstitusi Masjumi there was a section on Human Rights that constituted some rights such as right of equally treatment before the law, of religion, of freedom, of safety/welfare, of education, of property, of moving, of speech/expression. ${ }^{35}$

\section{On the Diversity in Indonesia}

Masyumi embraced a profound understanding that Indonesia was a pluralistic state, comprised of different groups of ethnics, and beliefs/religious adherents. This unique situation was accounted by Masyumi as "kurnia ilabi" (a gift from the God). ${ }^{36}$ In the Inilab Chittabku it is stated that the Indonesia's existence is a result of the long people's jihad (struggle) and therefore Masyumi sincerely took this nation with gratitude ${ }^{37}$ Furthermore, Masyumi believed that anybody, including Muslims, could not avoid Indonesian people diversity for any reasons let alone eliminate it. In fact, Islam upheld a principle that can be used as a basis for tolerance and honouring religious differences. ${ }^{38}$ In Inilah Chittable $u$ was stated that Islam was a political foundation that would be implemented as: "The way of life for the state that believes in rule of law, holds justice and maintains diversity among the citizens and inhabitants without exceptions". 39

Masyumi also believed that mutual relationships among people from different backgrounds or groups should be enacted ${ }^{40}$ and every

34 “Program Perdjuangan Masjumi”, p. 61.

35 Konstitusi Masjumi, Hasil Penyelidikan Panitia Kerja Chapter III Article 28-48. These rights were also published in Masyumi's Magazine. See Hikmah, 17th edition (21 Jun 1958), p. 6.

36 "Tafsir Asas", p. 45.

${ }^{37}$ M. Natsir, Inilah Chittabku (Djakarta: Penerangan Pimpinan Partai Masjumi, 1953), p. 5; M. Natsir, people-to put Masjumi, Pidato Mohammad Natsir dalam Peringatan Ulang Tahun ke-X Masjumi di Jakarta 1955 (Djakarta), p. 2.

${ }^{38}$ M. Natsir, "Islamic Tolerance", in Indonesian Political Thinking, 1945-1965, ed. by Herbert Feith and Lance Castles (Ithaca [N.Y.: Cornell University Press, 1970), p. 218.

${ }^{39}$ Natsir, Inilah Chittabku, p. 5.

40 "Anggaran Dasar Partai Politik Islam Indonesia Masyumi, Article IV", in Pedoman Perdjuangan Masjumi, 2nd edition (Djakarta: Pimpinan Partai Masjumi, Bagian Keuangan, 1955), p. 6. 
citizen deserved to hold government position. ${ }^{41}$ In other words, it was not only about acknowledging pluralism, but also the eagerness to express it throughout creating a prolific relationship. Also, faith, according to Masyumi was not the outcome of coercion, instead of a gift from God. ${ }^{42}$ Prawoto Mangkusasmito the latest Masyumi Chairperson even stated that Masyumi would accept if the adherents of other religions are also keen to put the obligation to implement of their religions in the state constitution. Mangkusasmito said:

For those who are non-Muslims, we proclaim that we do thoroughly not object if you want the warranty to implement the law of your religions to be present in those outlines (constitution, writer). ${ }^{43}$

Concerning the presence of different parties and organisations, Masyumi in Tafsir Asas regarded this phenomenon as a natural occurrence and as a situation that would motivate people to compete to be the best in providing good deeds. Masyumi refers to al-Quran (2:148), as a foundation for this point of view. ${ }^{44}$ Masyumi would not be afraid if other organisations led this country as long as democratic norms exist. ${ }^{45}$ From the above points of view, Masyumi confirmed its positive attitudes towards pluralism in Indonesia.

${ }^{41}$ Konstitusi Masjumi, Hasil Penyelidikan Panitia Kerja Article 41 Verse 2.

42 "Tafsir Asas", supra note 23, at p. 48. Masyumi found the foundation for this attitude in the principle of freedom of religion (there is no compulsion in religion) as stated in al-Quran (2:256). The complete translation of this verse is "There is no compulsion in religion. The right direction is henceforth distinct from error. And he who rejecteth false deities and believeth in Allah hath grasped a form handhold which will never break. Allah is Hearer, Knower". See this verse for instance in "Tafsir Asas", p. 48.

${ }^{43}$ Prawoto Mangkusasmito, "Jiwa dan Semangat 1945 Masyumi Menolak Suatu 'Machtstaat", in Alam Pikiran dan Jejak Perjuangan Prawoto Mangkusasmito: Ketua Umum (Affairs) Partai Masyumi, ed. by S.U. Bajasut and Lukman Hakiem (Jakarta: Penerbit Kompas, 2014), p. 104.

${ }^{44}$ That verse says: "And each one hath a goal toward which he turneth; so vie with one another in good works. Wheresoever's ye may be, Allah will bring you all together. Lo! Allah is able to do all things. See such Masyumi's attitude in "Tafsir Asas", p. 47.

${ }^{45}$ Prawoto Mangkusasmito, "Perjuangan Kita Masih Jauh, Belum Masanya Kita Memetik Buah”, Suara Masjumi, 11/12 edition (Djakarta, 1951); S.U. Bajasut and Lukman Hakim (eds.), Alam Pikiran dan Jejak Perjuangan Prawoto Mangkusasmito: Ketua Umum (Terakhir) Partai Masyumi (Jakarta: Penerbit Buku Kompas, 2014), p. 128. 


\section{E. The Attitudes and Policies Related to Pluralism in Politics}

The next discussion will analyse Masyumi's attitudes on pluralism. For this objective, this part will discuss relevant responses and policies on some matters or events. These include the response towards diversity in Islamic communities, the existence of non-Muslim and secular groups, and the party policies in general, dealing with some national issues.

\section{The Attitudes in the Context of Internal Islamic Communities Diversity}

Political diversity within Muslim groups is historical evidence. Some Islamic parties joined the 1955 Election, including Masyumi, Islamic Scholars Awakening Party (PNU), Indonesia Islamic Union Party (PSII) and Islamic Education Association (Perti). About this, Masyumi took some anticipatory positions. One of them was by respecting all the mazhabs or streams that existed and was implemented in Islamic communities. Two of four points in the Keputusan Majelis Syura on the existence of the madhhab stated that:

...(2) Masjumi wholeheartedly respects madzhab that are practised by the regular and special members,... (4) Masjumi will not intervene cbilafiah (religious interpretation) matters that would lead to fragmentation among Islamic communities. ${ }^{46}$

This party, hence, appreciated all Islamic groups to join Masyumi regardless their religious affiliations or streams. Some organizations, from different religious affiliation background, latter on were bestowed status as Anggota Istimewa (Special Member), joining Islamic Scholar Awakening (NU), Muhammadiyah and Islamic Community Association (PUI) as founders of Masyumi that have enjoyed this status since $1945 .{ }^{47}$ One of Masyumi's supporters claimed that it became Masyumi's characteristic for not intervening religious identity of its Special Members, let alone pushing them to leave their identity as modernist or traditionalist. ${ }^{48}$ The ulama from various backgrounds, both from traditionalist and modernist Islam

46 "Pertimbangan Madjlis Sjuro Pusat: Sikap Masjumi terhadap Mazhab", in Pedoman Perdjuangan Masjumi, 2nd edition (Djakarta: Pimpinan Partai Masjumi, Bagian Keuangan, 1955), p. 97.

${ }^{47}$ These organizations were NU, Muhammadiyah, Pesatuan Umat Islam, Perikatan Ummat Islam, Al-Jamiyatul Washliyah, Al-Ittihadiyah, Al-Irsyad, Persatuan Islam and Persatuan Ulama Seluruh Aceh.

${ }^{48}$ Hamka, Muhammadiyah-Masyumi (Jakarta: Masyarakat Islam), p. 44. 
camps occupied an important position in the party, mainly in the Majelis Syura (Consultative Board) to provide fatwa (religious stipulation) as a religious foundation for Masyumi's political manoeuvres. This function was never changed, even when NU left this party in 1952.

These situations, on the other hand, indicated a unique internal situation in Masyumi compare to other parties, in which this party tended to be a hut of politicians with different Islamic affiliations background. There were two MPs that openly acknowledged NU as their religious affiliation. ${ }^{49}$ In this case, Mahendera compares Masyumi as a craft that was fulfilled by passengers from different backgrounds, including people from non-strict Muslims (abangan) camp, persons with western education background and santri (strict adherent of Islam) groups. ${ }^{50}$ Effendy adds ethnicity as another cause that made diversity becomes so obvious in this party. The fact was this party was not only able to establish committees in all provinces but also had people with various ethnic backgrounds in the Central Committee. ${ }^{51}$

Moreover, the decision of PSII, and later NU, to leave Masyumi, did lead to disappointment but not trigger hatred to this party towards those parties. Masyumi was still willing to maintain good relationships with PSII and NU even not long after they decided to leave this party. In some aspects, the relationships between PSII and Masyumi became anxious ${ }^{52}$ and this also happened at the local areas. ${ }^{53}$ However, in general, this party was still eager to conduct relationships with PSII. This eagerness was reflected, for instance, by invitation for PSII to join the government. PSII figures were always included in most of "Masyumi cabinets". At the beginning of 1951, Natsir asked PSII to join his government. The agreement between Masyumi and PSII resulted in the appointment of Harsono Tjokroaminoto as the Second Vice-Prime Minister and Soedibjo as Minister of Social. Natsir Cabinet latter on was criticised by many as a fragile cabinet for the absent of PNI.

${ }^{49}$ Madinier, Partai Masjumi, p. 22.

50 "Seorang Besar dengan Banyak Teman", Tempo, no. 14-20 Juli (2008), p. 83.

${ }^{51}$ Ibid.

${ }^{52}$ Including in the case of responding Soekarno's concept on the Guided Democracy, in which PSII tended becoming more lenient than Masyumi.

${ }^{53}$ Kevin William Fogg, "The Fate of Muslim Nationalism in Independent Indonesia”, PhD Dissertation (New Haven: Yale University, 2012), p. 328. 
In general, securing political interest certainly was one of the main backgrounds of Masyumi and PSII relationship. Nevertheless, the power struggle concern was not the only reason. The commitment to hold unity among Islamic communities became another reason that pushed Masyumi to keep trying to preserve political networking among Islamic parties, regardless their religious streams. With that respect, many members of PSII eventually decided to return to Masyumi, mainly after realising that Masyumi's commitment to maintaining the unity of Islamic communities was close to Tjokoraminoto, PSII's great leader, teachings. ${ }^{54}$

In the meantime, the quite similar situation also happened between Masyumi and NU. There was a time when their relationship was considerably in an intricate situation. Months before the NU's decision to break up from Masyumi were highly difficult times. Disputes between NU and Masyumi, mainly the modernists in this party, seemingly recurred the "classic tensions" between the traditionalists and the modernists at the beginning of $20^{\text {th }}$ century. NU severely accused the modernists as the people that intentionally disrespected and ostracized ulama, particularly those with the NU's background..$^{55}$ On the other hand, the modernist cynically stated NU as incapable of doing real politics with limited understandings on how to politics should be managed. ${ }^{56}$ After the segregation in 1952, the tension between these parties still occurred. The campaign days previous to the 1955 Election became once again the period of tension between NU and Masyumi, in particular at the local areas. ${ }^{57}$ Some members and sympathiser form both sides pried up old matters mainly on different Islamic understandings and traditions, including on taqlid (unquestioning acceptance of religious traditions) and bid'ah (heresy) issues, ${ }^{58}$ to define their political stance and to downgrade the image of the opponent.

${ }^{54}$ Hamka, Muhammadiyah-Masyumi, p. 44. One of them was Amelz, PSII leaders, who were dissatisfied by his former party consents to enlist Ali Government. Amelz regarded such a decision as viciousness for Islamic unity.

${ }^{55}$ Madinier and Feillard, "At the Sources of Indonesian Political Islam's Failure", pp. 12-20 supra note 7; Noer, Partai Islam di Pentas Nasional, pp. 93-4.

${ }^{56}$ Noer, Partai Islam di Pentas Nasional, p. 96.

${ }^{57}$ Herbert Feith, Pemilihan Umum 1955 di Indonesia (Jakarta: Kepustakaan Populer Gramedia, 1999), pp. 23-4; Fogg, “The Fate of Muslim Nationalism”, pp. 322-6.

${ }^{58}$ Noer, Partai Islam di Pentas Nasional, p. 371.. 
However, the relationship between NU and Masyumi was not always in the constant high tension. At the elite level, the situation is considerably more unperturbed and cooperative. Some elite figures, such as Sukiman or Jusuf Wibisono, even sometimes felt more comfortable with the NUs rather than with their fellows Masyumi members. In the 1952 Palembang Conference, on the occasion where the decision to quit from Masyumi was announced, for instance, Sukiman as a "friend of NU" was there. In that event, Sukiman witnessed such announcement and kept silent as he thought he had no rights to speak. ${ }^{59}$

Masyumi did not want to have distance with NU. In every cabinet that was formed by Masyumi, for instance, some political figures with the NU's background were always joined. In the Burhanuddin Harahap Cabinet, the first and the last Masyumi cabinet after the 1952 NU resignation, there were two NU figures, namely Soenarjo as the Minister of Interior, one of prestigious position in government, and Iljas who held Minister of Religion post. The policy to distribute some important political posts to NU indicated the eagerness of Masyumi to keep opening political access for NU and in general to be involved in the decision-making process. This attitude was easy to conduct since Masyumi has already a set of thoughts for respecting pluralism in politics as the foundation. However, this attitude also was based on the interest to maintain Islamic interest in general, including ensuring political embargo for PKI continuation.

In relation to the NU's decision to leave Masyumi, many people believe that this was a sensible result of Masyumi modernist wing' manoeuvres to restrict NU' roles in this party, primarily by limiting the role of Majelis Syuro. ${ }^{60}$ However, many other people believe that even though some of Masyumi's exponents indeed tended to be more insensitive regarding on the ulama position, ${ }^{61}$ it was a political interest that

\footnotetext{
${ }^{59}$ Ibid., p. 240.
}

${ }^{60}$ Mahrus Irsyam, Ulama dan Partai Politik: Upaya Mengatasi Krisis (Jakarta: Yayasan Perkhidmatan, 1984), p. 27; Greg Fealy, Ijtihad Politik Ulama: Sejarah NU 19521967 (Yogyakarta: LKiS, 2003), pp. 109-13; Madinier and Feillard, "At the Sources of Indonesian Political Islam's Failure", pp. 12-3 supra note 7.

${ }^{61}$ Noer, Partai Islam di Pentas Nasional, pp. 93-4. 
should be counted as the main reason of NU withdrawal, ${ }^{62}$ the need to channel NU politicians' interests, on the other hand, which getting bigger in terms of number for time to time, was also another important reason. ${ }^{63}$

The relationship between Masyumi's elites and other traditionalist people or groups, however, was well maintained. Some Masyumi's Special Members, such as Al-Jamiyatul Washilyah, Nahdlatul Wathan or Al-Ittihadiyah were the traditionalist. Until days before the Masyumi dissolution, these organisations were still part of this party. Their loyalty to some extent could not happen if they faced similar problems with NU. This situation indicates that these organisations had quite different experiences with NU, in which their ulamas, as the most respective figures, were treated considerably well and felt more comfortable with other Masyumi members with different religious affiliation backgrounds. From time to time they could build a solid interaction with modernists groups or with the elites with Western educational background. ${ }^{64}$ Not only that, some people believe Masyumi became a melting pot that increased enthusiasm of the members to know each other and to be more tolerant with religious backgrounds. ${ }^{65}$

In relations to the minorities, such as Ahmadiyah, Masyumi did not pay intense attentions or provide special treatment for them. In the case of Ahmadiyah, Masyumi, in fact, did not include it as part of Special Member or invited this organisation to join. In the dawn of Masyumi life, no Special Members agreed to include Ahmadiyah as party's member. The main reason for this attitude was that those organisations believed that Ahmadiyah did not follow the teachings of ablussunah wal jamaah (Sunni). ${ }^{66}$ Hence they did not see the need to persuade Ahmadiyah to be part of Islamic movement or party. Even though Masyumi, and the majority of Muslims in that time, seemed reluctant to acknowledge Ahmadiyah as part

${ }^{62}$ Noer, for instance, suggests that the push factor for NU to leave Masyumi was actually its political interest, namely to secure the ministry of religion post in the Wilopo Cabinet. Ibid., p. 67; Audrey Kahin, Islam, Nationalism, and Democracy: A Political Biography of Mohammad Natsir (Singapore: NUS Press, 2012), pp. 94-5.

${ }_{63}$ Mahendra, Modernisme dan Fundamentalisme, pp. 150-1; Fealy, Ijtihad Politik Ulama, pp. 117-8.

${ }^{64}$ Noer, Partai Islam di Pentas Nasional, pp. 68-103.

${ }^{65}$ Hamka, Muhammadiyah-Masyumi, p. 31.

${ }^{66}$ Noer, Partai Islam di Pentas Nasional, pp. 53-4. 
of the Islamic community, it was quite evident that this party has never officially suggested anyone abandon let alone assault Ahmadiyah group. ${ }^{67}$ In relation to the existence of the Islamic State (Darul Islam, DI) movement, ${ }^{68}$ Masyumi had actually similarity with this radical movement in terms of believing that Islam should have central role in the life of the people, society and state. ${ }^{69}$ In fact, most of DI important leaders were the former member of this party. ${ }^{70}$ However, they varied on the attitudes and strategies in pursuing ideas. Sjafruddin Prawiranegara, one of the Masyumi elites, for instance, regarded the establishment of the $\mathrm{DI}$ as pointless and as nothing but the phenomenon of putting forward the label rather than the substance. He also criticised the use of violence and mistrusted DI as the ideal-state for Indonesian people for that reason. He then suggested Indonesian people reject DI as hard as possible. ${ }^{71}$ Regarding strategy, Masyumi believed in the implementation of peaceful

${ }^{67}$ The personal relationship of some Masyumi's figures with Ahmadiyah members were quite warm. One of the Masyumi's figures and MPs, Mahmud Latjuba was the founder of Indonesia Ahmadiyah Movement (GAI) Lahore Centrum, on 28 December 1928. In that time Ahmadiyya Bewegung was the name of this movement; Ahmad Gaus A. F, Sang Pelintas Batas: Biografi Djohan Effendi (Jakarta: ICRP dan Penerbit Buku Kompas, 2009).

${ }^{68} \mathrm{DI}$ movement proclaimed the establishment of Indonesia Islamic State or Darul Islam on August $7^{\text {th }}, 1949$. This state was based on Islam and as a consequence would implement Islamic laws, norms and traditions to the citizens and anyone who lived under its jurisdiction. For those who rejected Islamic laws or Imam, DI would take serious actions, including perishing them. See Irfan S. Awwas, "Kitab Undang-Undang Hukum Pidana Negara Islam Indonesia, Article 3", in Jejak Jihad SM. Kartosuwiryo: Mengungkap Fakta yang Didustakan (Yogyakarta: Uswah, 2008), pp. 159-60.

${ }^{69}$ On the reasons and objectives of the rise of DI Movement see Cornelis Van Dijk, Darul Islam : Sebuah Pemberontakan (Jakarta: Grafiti Pers, 1983); Holk H. Dengel, Darul Islam dan Kartosunirjo: Angan-angan yang Gagal (Jakarta: Pustaka Sinar Harapan, 1995); Adhe Firmansyah, S.M. Kartosoewirjo: Biografi Singkat, 1907-1962 (Yogyakarta: Garasi, 2009), pp. 25-45; Irfan S. Awwas, Jejak Jibad SM. Kartosuwiryo: Mengungkap Fakta yang Didustakan (Yogyakarta: Uswah, 2008), pp. 117-22.

${ }^{70}$ Kartosuwiryo, former Masyumi Chairman, was the founder of DI, who declared and led this Movement in West Java. In Aceh, Daud Beureuh, the leader of PUSA, one of Masyumi's Special Members, was the leader of this movement. In the mean time, in many remotes areas, ex-members or sympathisers of Masyumi took part to establish this movement.

${ }^{71}$ Ajip Rosidi, Sjafruddin Prawirangegara Lebih Takut Kepada Allah SWT (Jakarta: Inti Idayu Press, 1986), pp. 142-3. 
approach as the best method for Muslim to fight for the ideal state. In the Tafsir Azas, it was clearly stated that "Masjumi does not approve of anyone or groups in this country to employ force or violent towards others in reaching their goals" .72

This attitude, of course, was in the different direction from the DI's outlook, which in fact preferred to set up armed forces and fight violently. To explain the differences between them, Masyumi then declared an announcement. This announcement stated that:

...(3) concerning above matters, the Party Executive Board regards that it is important to announce a plain explanation on the political stance differences between Masyumi and Darul Islam movement, (4) Masjumi would attain its objectives throughout Democratic-Parliamentary ways, and in agreement with the state constitution and all state regulations. (5) Through this clarification, it is hoped that different stances between Masjumi and Darul Islam movement become clearer. ${ }^{73}$

Although Masyumi opposed DI's violent strategies and in general rejected its existence, this party refused military approaches, supported by the government and mainly PNI and PKI, to end the adventure of this movement. Instead of concurring aggressive methods, Masyumi consistently advised the government to put forward a dialogue. Moreover, Masyumi also proposed the government to forgive those who had involved in the movement and provided reasonable compensation for their willingness to surrender. ${ }^{74}$ Masyumi also believed that this approach which should soon be followed by the commitment to build prosperity might change their opinion about the government and Indonesia state. ${ }^{75}$

\section{The Attitudes toward Non-Muslim Minority Groups}

Masyumi's attitudes and treatments towards minority political groups could be traced from the official policies and its elite's behaviours. During its existence, there were two important parties that were established by non-Muslim minorities namely, the Indonesia Christian

72 “Tafsir Asas", p. 55.

${ }^{73}$ Rémy Madinier, "Berita Masjumi, 24 January 1952”, in Partai Masjumi: Antara Godaan Demokrasi \& Islam Integral (Bandung: Mizan, 2013), p. 158.

${ }^{74}$ Hendra Gunawan, M. Natsir dan Darul Islam: Studi Kasus Aceh dan Sulawesi Selatan Tabun 1953-1958 (Jakarta: Media Da’wah, 2000), pp. 23-4.

${ }^{75}$ Ibid., pp. 4-11. 
Party (Parkindo) and the Catholic Party of Republic of Indonesia (PKRI). Masyumi's pledge on the establishment of a state based on Islamic law and norms was of course not in favour with both Christian Parties' ideals. In fact, both Parkindo and PKRI were the true believers for $a$ Pancasila-based state. For many Christians, a Pancasila state would bring more guarantees for freedom of religion. ${ }^{76}$ Masyumi, however, kept maintaining mutual relationship with these non-Muslim parties, albeit differences political stances between them.

Masyumi, for instance, always included elites from PKRI and Parkindo in its cabinets. In the Natsir Government, Harjadi (PKRI) was selected to be Social Minister and Leimena (Parkindo) as Health Minister. In the Sukiman Government, there were also two Christian leaders, namely Leimena who still hold Health Minister and Suwarto (PKRI) as Agriculture Minister. Meanwhile, in the Burhanuddin Harahap Government, two PKRI's elites were appointed as a member of cabinet namely, Kasimo (the Chairman of PKRI) who becomes Economic Minister and Suwandi as Education, Teaching and Culture Ministers; while Leimena is again selected to be Health Minister. The willingness to hand over Economic Minister, one of the most significant posts, to Kasimo proved Masyumi's commitment to providing noteworthy political access to the minority. Moreover, to contain Soekarno's effort to bring about Guided Democracy, which was essentially an authoritarian political system, Masyumi together with PSI, Parkindo, PKRI, IPKI and other parties established the Liga Demokrasi in 1960.

The fact that minorities were willing to build cooperation with Masyumi indicated the presence of trust among them. Some believed that such trust grew over time as political relationship between Masyumi and minorities became more intense. ${ }^{77}$ Masyumi indeed needed solid supports from PKRI and Parkindo to be able to survive and maintained equilibrium towards political manoeuvres of PNI and the communists. Likewise, PKRI and Parkindo needed Masyumi to have real access to the centre of power and decision-making process. However, this positive

${ }^{76}$ Risalah Perundingan Tabun 1957 Sidang ke-III (Konstituante Republik Indonesia, 1957) Rapat ke-28 ; ibid., p. 504 Rapat ke-33.

${ }^{77}$ Yusril Ihza Mahendra, Rekonsiliasi Tanpa Mengkhianati Reformasi: Versi Media Massa, ed. by Andang B. Malla, M. Saleh Mude, and M. Fuad Nashar (Jakarta: Teraju, 2004), p. 33. 
situation was also shaped by the close relationship between parties' leaders from both camps. The intimate relation between Natsir and Kasimo had been one of the great memories among political leaders in that time. In the Eid Day, for instance, Kasimo and his family came to Natsir's home to celebrate this one of the most important days in Islamic calendar. Likewise, Natsir always attended to Kasimo's home on the Christmas Day. ${ }^{78}$ According to Natsir's daughter, Natsir sent the family of Kasimo and Leimena bunch of flower to celebrate New Year. ${ }^{79}$

In the friendship context, the warm attitudes of Masyumi's figures towards non-Muslim had been witnessed by many people. In general, they reckoned Masyumi's elites as Democrats that sincerely respected nonMuslim peoples. Sumual, for instance, for instance, said that the leader of Masyumi, like Natsir, was a national leader who was very tolerant towards all groups, in which could accept any diversity and differences.

The close relationship between Masyumi and Christians Parties were related to the political interest to win the power struggle. However, if we look into relations among parties leaders, it is fair to conclude that the relationship between Masyumi and non-Muslim minority groups was much deeper and more than just political relations. Oetama's note describes such a relation appropriately. He says:

I was impressed by the warm relationship, even a brotherhood relationship, between Pak Natsir, along with other Masyumi figures, and Pak Kasimo, the leader of Catholic Party. The friendship between Pak Natsir, Pak Mohammad Roem, Pak Prawoto and Pak Kasimo was very touching... Different opinions even conflict opinion in political thought did not ruin their friendship and brotherhood. ${ }^{80}$

${ }^{78}$ Chris S.K. Timu, "Natsir, Aspirasi Islam dan Komunitas Katolik", in 100 Tabun Mohammad Natsir, ed. by Lukman Hakiem (Jakarta: Penerbit Republika, 2008), pp. 68-9.

79 "Tangis untuk Mangunsarkoro", Tempo, no. 14-20 Juli (2008), p. 89.

${ }^{80}$ Jacob Oetama, "Mohammad Natsir: Jujur dalam Sikap, Santun dalam Tindakan", in 100 Tabun Mohammad Natsir, ed. by Lukman Hakiem (Jakarta: Penerbit Republika, 2008), p. 40. 


\section{The Attitudes toward Secular Groups (Nationalists and Socialists)}

The secular parties were the main obstacles for Masyumi's attempts to establish Islamic law-based state. PNI and Socialist Party of Indonesia (PSI) were among the influential parties that represented these secular parties.

Masyumi was involved in a strong rivalry with PNI, in many aspects. At the discourse level, dispute on the state foundation in parliament was momentous and above all signified a very fundamental ideological divergence between PNI and Masyumi. ${ }^{81}$ For nationalists, the idea of an Islamic state, which was believed by Masyumi, was out of date, irrelevant and intolerant. ${ }^{82}$ On the other hand, Masyumi opposed the concept of Guided Democracy and Nasakom (Nationalist, Religion and Communist unity) idea that were supported by the PNI. In terms of actions, to shake each rival position became part of the real power struggle for Masyumi and PNI to conduct. This aim sometimes put them in the severe situation, causing a down fall of cabinets. PNI also always involved in the political manoeuvres that ended Masyumi led governments. Likewise, Masyumi tended to be the main supporter to criticise PNI led governments.

However, Masyumi and PNI relationship was not always overwrought. They could actually build a prolific and solid engagement, putting forward national interests above theirs. They became very close tandem in some very critical moments, including in facing Dutch second aggression and Communist mutiny in 1948. Both Masyumi and PNI were using internal rivalry and difference tendencies as political bargains to retain more advance position. In this case, there was a unique situation in Masyumi and PNI relationship, when sometimes a faction in PNI could build collaboration with a preferred faction from the Masyumi. ${ }^{83}$

Sukiman faction, for instance, was more in favour to build a

${ }^{81}$ The debate between Natsir and Soekarno, in years prior to independence era, was a classic example and became inspiring deed for both sides afterwards; Ahmad Suhelmi, Soekarno versus Natsir: Kemenangan Barisan Megawati, Reinkarnasi Nasionalis Sekuler (Jakarta: Darul Falah, 1999).

${ }^{82}$ Mahendra, Modernisme dan Fundamentalisme, p. 75.

${ }^{83}$ Herbert Feith, The Decline of Constitutional Democracy in Indonesia. (Ithaca N.Y.: Cornell University Press, 1968), pp. 146-557; Lucius, Robert E, "A House Divided: The Decline and Fall of Masyumi (1950-1956)", Master's Thesis (Monterey: Naval Postgraduate School, 2003), pp. 71-157; Noer, Partai Islam di Pentas Nasional, pp. 159-276. 
coalition with so-called "radical wing" faction in PNI. On the other hand, Wilopo faction was more accommodative to Natsir faction. This provoked tricky situation for the cabinet establishment. Some cabinet became very nuanced by modernist-Natsir orientation with the more "problem solver outlook", rigid in national budget management and having PSI, PKRI and Parkindo as the main allies, just like what happened in the Cabinet of Natsir, Wilopo and Burhanuddin Harahap. On the other hand, other cabinets tended to be in accord with the PNI radical wing, led by person like Sidik Djojosukarto, which was inclined putting forward more aggressive-nationalistic agendas and anti-PSI. However, even though it was complicated, the relationship between these parties still continued until the late 1950s. This continuation in many aspects proves that both Masyumi and PNI were keen to have a talk. Masyumi kept opening a chance to built compromise and cooperation with PNI, and indirectly admitting PNI's imperative position in Indonesian politics circumstance. $^{84}$

If a complicated relationship signified the Masyumi and PNI connections, the more lenient and stable one happened between Masyumi and PSI. In the early years of independence era, some policies of PM Syahrir were questioned by Masyumi, which regarded those policies as improper, including the government system that was switched from presidential to parliamentarian and several controversial diplomatic agreements. However, over time the more understanding gesture occurred, and the previous relationship characters soon were replaced by the growth of common understanding between them. In Feith and Castles political ideology of Indonesia parties map, the tangent points between the ideology of PSI and Masyumi was larger than PNI and Masyumi had. ${ }^{85}$

${ }^{84}$ In the Indonesian history, the Natsir Cabinet was the only Masyumi led cabinet that excluded PNI. It happened after PNI refused to join the cabinet, caused primarily by the disagreement on the cabinet composition. Initially Natsir, as formateur, wanted to return the mandate to Soekarno for this failure. However, the president kept suggesting him to try creating cabinet one more time. When Natsir finally succeeded in composing government by involved in some mediocre nationalist parties in his cabinet, namely Great Indonesia Party (Parindra) and Great Indonesia United Party (PIR), Soekarno supported him to run the government.

${ }^{85}$ Feith and Castles, Indonesian Political Thinking 1945-1960, pp. 14. 
This concludes many similarities between PSI and Masyumi in thinking and the way they responded to the political developments. They both, for instance, were the supporters of a pragmatic government, in which believed in rational approaches rather than putting forward nationalist sentiment in creating policies. Together with PSI, Masyumi particularly under the Natsir leadership built a government that latter on was popularly known as an administrator, which tend to be closer to Hatta rather than Soekarno.

Masyumi and PSI worked hand in hand very closely to implement the policy to reorganise military structure and to rationalise the number of military members, which was something delicate to do by the fact that many ex-combatants were not in favour of this policy. Furthermore, both parties preferred enduring a discipline in national budging expenditures and believed in the beneficial gains of the foreign investors to the country development. They also were the supporter of democracy and people sovereignty, in which the PSI democracy social ideals seems in line with the Masyumi's spirit of Islam. In this case, Masyumi and PSI in 1950 became the frontrunner for the denunciation manoeuvres towards the idea of Guided Democracy that made their relationship with Soekarno became even worse.

However, not all members of Masyumi had a similar opinion towards PSI. Soekiman and his groups, for instance, tended to keep distance with PSI and at the same time established close relationship with the nationalists. ${ }^{86}$ Soekiman was the man that adored Soekarno and before the implementation of Guided Democracy tended to not criticise the president publicly. Nevertheless, the figures like him and Jusuf Wibisono at heart were also a true believer in the pluralism, which eventually brought them to the similar situation with the more proPSI faction in Masyumi. In fact, Soekiman Government was the most aggressive government compare to other Masyumi led cabinets towards the communists. This attitude, of course, was in accordance to the PSI's attitudes to the communists.

Above explanations indicate that the relationship between Masyumi

${ }^{86}$ Muchtaruddin Ibrahim, Dr. Sukiman Wirjosandjojo, Hasil Karya dan Pengabdiannya (Jakarta: Departemen Pendidikan dan Kebudayaan, Direktorat Sejarah dan Nilai Tradisional, Proyek Inventarisasi dan Dokumentasi Sejarah Nasional, 1982), p. 100. 
and PSI was better than its relationship with PNI. However, in general, the relationship between Masyumi and PNI was still in the pluralism corridor. Some people believe that the considerably good relationship between Masyumi and the secular groups was mainly based on the political interest rather than sincere motives. This thought was true to some extent. However, if we see Masyumi' concepts on how to conduct a relationship, the positive attitudes such as accommodating and tolerating secular groups were one of the normal consequences.

\section{The Attitudes towards the Communists}

In its short period of life, Masyumi was popularly known as a party that consistently and comprehensively rejected Indonesia Communist Party (PKI) and communism. Masyumi and PKI grew as rival and had basic differences in almost all aspects. They each possessed ideology which was not fit each other, and as a result, they were involved in a never-ending ideological war. This war was expressed by Masyumi and its followers in many ways, including by publishing articles, papers or books. ${ }^{87}$

Masyumi stipulated proposal to the Indonesian people to leave PKI. Majelis Syuro Masyumi stated that every Muslims that were member or sympathiser of PKI and also had a deep understanding of the Marxism/ Communism had plunged to be a kafir (unbeliever). The Masyumi's anticommunism attitude also derived from the total disagreement on the concept of dictator proletariat importance. A Democratic government that was strongly proposed by Masyumi was contradictory in many aspects with such PKI's faith. Moreover, PKI's argument on the two conflicting groups, bourgeoisie and proletariat, which every human being would belong to one of those two groups quite deteriorated the fact of human diversity, believed by Masyumi, as the result of the God's will. Hence, the acknowledgement of freedom of expression and human diversity were some of the focal points that induced Masyumi's resistance towards communism.

Masyumi had also implemented political manoeuvres to compete with PKI and at the same time contained this party augmentation. In

${ }^{87}$ Samsuri, "Media Pendidikan Politik Anti-Komunis", in Politik Islam Anti Komunis: Pergumulan Masyumi dan PKI di Arena Demokrasi Liberal (Yogyakarta: Safiria Insania Press - Magister Studi Islam, Universitas Islam Indonesia, 2004), pp. 95-104. 
some areas, the cadres and members of both parties were involved in quite solemn clash. ${ }^{88}$ Furthermore, prior to the 1955 Election, all Masyumi's propaganda tools, including Masyumi founded mass media such as $A b a d i$ daily newspaper and Hikmah weekly magazine, discussed in daily basis the dangers of communism and PKI ${ }^{89}$ At the level of government, Masyumi rejected any possibility to form a government with the communists. ${ }^{90}$

About the PKI, it is clear that Masyumi rejected to establish any cooperation or build common access, let alone establish mutual coexistence, with the communists. Masyumi, instead, tended to be absolute by regarding the communists as infidel and PKI's blind supporters as misguided. To some extent, these attitudes seemingly were contradictory with the spirit of pluralism. However, the main reasons for such attitudes were related to the concern to defend democracy, individual rights and also pluralism. Hence, to preserve diversity in politics was one of the backgrounds of Masyumi's anti-PKI attitudes.

\section{Other Policies}

When it became part of central government, Masyumi tended to put forward the interests of the nation rather than only Muslims' interests. It was reflected, for instance, by its intense involvement in the struggle to fight for state sovereignty, through diplomacy or war, including establishing the Emergency Government of the Republic of Indonesia (PDRI) in the West Sumatra, led by Prawiranegara, rather than creating

${ }^{88}$ Madinier, Partai Masjumi, pp. 140-1.

${ }^{89}$ In Hikmah weekly magazine, for instance, there was a column dedicated to criticizing institutions that were regarded as opposition of Masyumi, named "Lawan dan Kawan", in which was mainly used by Masyumi to attack PKI in almost all aspects particularly prior to the 1955 Election. See for instance, "Mendewakan Presiden untuk Alat Perjuangan: PKI dan PNI Matjam”, Hikmah, 39th edition (24 Sep 1955), p. 17; "Komunis Penindas Rakyat", Hikmah, 40th edition (1 Oct 1955), p. 17; "Nama PKI. Riwayat yang Tidak Banyak Diketahui Orang. Mengapa Saya Keluar dari Pergerakan Komunis", Hikmah, 40th edition (8 Oct 1955), p. 16; "PKI Pembela Negara Asing", Hikmah, 38th edition (17 Sep 1955), p. 14.

${ }^{90}$ This message was so clear. Thus, any political groups that wanted Masyumi to join their coalition would never offer or include PKI as part of the government. The Sukiman government even agreed to arrest thousand people that were suspected as communists under the policy that latter on was popularly called as "Razia Augustus 1951". Masyumi also supported anti-communist movements, including the Anti-Communist Forum, established by K.H Isa Anshary, one of Masyumi's leaders, in 1954. 
an Islamic State. This party also strongly proposed West Papua to be a part of Indonesia's territory, which would guarantee more the unity and sovereignty of the Indonesian state. Masyumi even did not recommend the concept of jiayah (a tax subject to non-Muslim citizens). According to Masyumi, every Indonesian citizen had similar rights and must be treated equally, hence treating people, including how they should pay the tax, based on their religion was not relevant for a nation-state based country. ${ }^{91}$

Masyumi in some cases also implemented realistic approaches to reach its objectives, in a sense that opened compromise to other groups by suggesting something that more acceptable by all. In the educational context, for instance, Masyumi eventually agreed to make a compromise with the secular groups to set religion teaching as a non-compulsory subject in schools, ${ }^{92}$ which different with its previous proposal. ${ }^{93}$ The willingness to put forward compromise had also been taken in the state's ideal foundation struggle. After prolonged debate and discussion, Masyumi eventually agreed on the establishment of the state that was not only based on Islam but also other religions, thus basically a statebased on religions. ${ }^{94}$

${ }^{91}$ Zainal Abidin Ahmad, Membentuk Negara Islam, ed. by Andang B. Malla et al. (Jakarta: Teraju, 2004), p. 284. The Masyumi's ideal economic system that was close to the socialist economic system was quite reflecting a tendency to anti-capitalism and colonialism. With this kind of belief, Kahin reckons Masyumi as the adherent of "religious-socialism", see George McTurnan Kahin, Nationalism and Revolution in Indonesia (Ithaca: Cornell University Press, 1952), p. 157. In this case, protection should be given to all groups regardless their social status or primordial background

${ }^{92}$ Prawoto Mangkusasmito, Masyumi dan Undang-Undang tentang Pendidikan dan Pengajaran di Sekolah, ed. by S.U. Bajasut and Lukman Hakiem (Jakarta: Penerbit Buku Kompas, 2014), pp. 69-74.

${ }^{93}$ Masyumi previously proposed that religion teaching must be provided by every school and it was compulsory. On the concept of Masyumi towards eduction see for instance Rahmah el-Junusijah and Kahrudin Yunus, Djalan Lurus dalam Pendidikan Putera/ Puteri, Agama dan Ekonomi (Djakarta: Fikiran Baru, 1956). In the educational context, however, Masyumi stated its program as "state constitution based educational system" rather than "Islamic educational system", see Konstitusi Masjumi, Hasil Penyelidikan Panitia Kerja Article 20.Masyumi proposed that all the citizens have to join the school at least up to primary level and supported subsidy to the private schools, including ones that were run by religious NGOs from any religious affiliations, see"Program Perdjuangan Masjumi", p. 63.

${ }^{94}$ One part of this agreement stated that: “....The Republic of Indonesia state, which is based on the will to bring about socialist society under the spirit of the one and 
Adnan Nasution said that before the Badan Konstituante (the parliament) dismissal, some leaders of this body gather to compromise on the model of Indonesia ideal state. According to Nasution "they agreed that democracy should be protected to save pluralism, the ideals of law-based state... also to respect human rights". ${ }^{95}$

Other momentous attitude that reflects pluralism in political deference was the Masyumi opposition towards Guided Democracy, a controversial authoritarian predisposition political concept founded by Soekarno in 1959. This concept forecasted an ideal Indonesian style democracy led by the spirit of collectivism and deliberation in the name of all people, not individual or group. The first and foremost reason behind this idea was creating more stable political system that eventually could guarantee prosperity and national security continuation. Critique of this concept was mainly related to the actor that entitled to represent all people, which in fact was the one and only Soekarno itself.

This concept regarded figure like Soekarno as the true representation of people's will. As the leader of the state and the government at the same time, he also had right to determine all the government policies. The army and the PKI supported President policy. After decades in the peripheral position, all three reckoned that the president conception was an entry point to take over the power and establish more advantageous political position. After Soekarno had stipulated this policy, Indonesia entered a new political milieu, in which the opposition was forbidden, and political diversity was suppressed. The new government not only restricted political participations but also latter on dismissed two important political parties namely Masyumi and PSI. For Masyumi the idea of Guided Democracy would certainly restrict the freedom of thought and will. The fact was Soekarno himself appointed who would be the members of DPR-GR (parliament) and stipulated direction for the state's basic policies. In the situation where the president had the right to determine anything, Masyumi believed that the role of parliament and

only God, in a sense that a state that is able to guarantee a comprehensive social justice and equal prosperity according to Islam, Christianity, Catholicism and other religions that exists in our country...", see "Risalah Sementara Sidang Konstituante, Sidang I, Desember 1957”, in Mahendra, Modernisme dan fundamentalisme dalam politik Islam, p. 212. 95 “Dasar Negara Islam tidak Dapat Dipaksakan", Tempo, no. 14-20 Juli (2008), pp. $86-7$. 
constitution would be artificial. ${ }^{96}$

The dismissal of Badan Konsituante and re-enacted of UUD 1945 (the 1945 Constitution), as the first realisation of Guided Democracy, really upset Masyumi, that regarded it as a setback in political life. Masyumi rejected this concept. ${ }^{97}$ Masyumi's stance was clearly expressed by Mangkusasmito. He said that this kind of movement would create a power based state (machstaat) which the parliament would also be very depended on the president. ${ }^{98}$ This condition was not in accordance with the Masyumi's ideal of law based stated (rechtstaat). As the reaction to this idea, on March 24 $4^{\text {th }}$, 1960, Masyumi together with other parties found Democracy League, demonstrating the will of protecting democracy and passed the message of the danger of Soekarno's concept on the people sovereignty future. ${ }^{99}$ This action completed Masyumi individual action that continuously conveyed resistance through its leaders and MPS in many occasions.

In the circumstance where the military was not in favour of democracy and, in fact, backed the president up to implement his policy, Masyumi antagonism was futile. Some people even regarded Masyumi as too stubborn and impractical. Masyumi indeed chose to fight and acted as a moving spirit for Soekarno's Guided Democracy censure. This attitude again indicates a high commitment to defend democracy, particularly pluralism in politics, although this party must pay a very high price for it.

${ }^{96}$ Prawoto Mangkusasmito, "Apakah Ada Manfaatnya Pembentukan MPRS? Karena Haluan Negara toh Sudah ditetapkan", in Alam Pikiran dan Jejak Perjuangan Prawoto Mangkusasmito: Ketua Umum (Terakbir) Partai Masyumi, ed. by S.U. Bajasut and Lukman Hakiem (Jakarta: Penerbit Buku Kompas, 2014), pp. 174-5.

${ }^{97}$ Prawoto Mangkusasmito, "Pesan Terakhir PP. Masyumi Amanat Umat telah Ditunaikan”, in Alam Pikiran dan Jejak Perjuangan Prawoto Mangkusasmito: Ketua Umum (terakhir) Partai Masyumi, ed. by S.U. Bajasut and Lukman Hakiem (Jakarta: Penerbit Buku Kompas, 2014), p. 144.

${ }^{98}$ Mangkusasmito, "Jiwa dan Semangat 1945 Masyumi Menolak Suatu 'Machtstaat", pp. 90-105.

${ }^{99}$ Prawoto Mangkusasmito, "Rugi Untung Perjuangan Harus dinilai dengan Rugi Untungnya Islam”, in Alam Pikiran dan Jejak Perjuangan Prawoto Mangkusasmito: Ketua Umum (Terakhir) Partai Masyumi, ed. by S.U. Bajasut and Lukman Hakiem (Jakarta: Penerbit Buku Kompas, 2014), p. 153. 


\section{F. Concluding Remarks}

The discussion above comprises two main measured matters to Masyumi's commitments towards pluralism, namely the point of view and attitude. This paper understands pluralism as a belief that covers four elements, which all four to be used as an indicator for the present of the political pluralism in Masyumi. From the above discussion, it is clear that generally, Masyumi has fulfilled all aspects of those four indicators.

In the point of view aspect, Masyumi believed in the law-based state that held democracy and diversity. This party had formally made a clearance on the equal rights that should be possessed by all citizens. This party also stated their commitment to respect pluralism, in which differences between groups should be acknowledged and accommodated. Masyumi's point of view also inferred the readiness to open dialogue and have mutual relationships with other political groups.

On the Masyumi's attitudes towards pluralism, above discussion indicates that this party was eager to build cooperation and provide opportunities to join strategic political positions to other groups, including non-Muslim groups or people. In many cases, Masyumi became a strong believer on the dialogue and compromise as the main tools to solve problems, including towards the secular nationalists and Muslim radicals.

The Masyumi's attitudes, in general, were a mixture of practical responses and Islamic idealism towards political developments. In this case, the purpose of winning power pushed Masyumi to conduct moderate actions, including how to properly deal with diversity and make it more productive for securing its political agendas. However, the above explanation also indicates that Islamic ideals also played the role as a foundation for Masyumi, and that includes of having constructive behaviour on pluralism. Above all, those cores of feat, in the end, have shaped a set of the positive attitude towards pluralism in politics.

However, even though having those positive tendencies, there were some parts of this party's thought or attitude that remained flaw. The belief that only Muslims should hold president and vice-president positions inferred an absolute thought, even though the reason behind this view was related to the fact that the majority of Indonesian, around $90 \%$ at that time, was Muslim. Furthermore, Masyumi's persistence to keep uncompromised towards the communists to some extent indicating 
a contradiction to neither mutual respect nor sprit of co-existence with different groups of people. To protect pluralism, however, was the prima cause behind its stance to be hard towards the communists.

Also, the above discussion demonstrates that Islamic party like Masyumi could independently develop a set of thought and real actions that were generally speaking, were in line with the spirit of pluralism. Islam in Masyumi's understanding was the foundation to be positive in dealing with diversity. The thought and attitude of Masyumi to some extent represented the real characteristics of the majority of Muslims and Indonesian in general which is still present up until today. 
The View and Attitude of Masyumi towards Pluralism in Politics

\section{BIBLIOGRAPHY}

Ahmad, Zainal Abidin, Membentuk Negara Islam, ed. by Andang B. Malla et al., Jakarta: Teraju, 2004.

“Anggaran Dasar Partai Politik Islam Indonesia Masyumi”, Pedoman Perdjuangan Masjumi, $2^{\text {nd }}$ edition, Djakarta: Pimpinan Partai Masjumi, Bagian Keuangan, 1955.

Awwas, Irfan S., "Kitab Undang-Undang Hukum Pidana Negara Islam Indonesia, Article 3", in Jejak Jihad SM. Kartosuwiryo: Mengungkap Fakta yang Didustakan, Yogyakarta: Uswah, 2008.

----, Jejak Jihad SM. Kartosuwiryo: Mengungkap Fakta yang Didustakan, Yogyakarta: Uswah, 2008.

Bajasut, S.U. and Lukman Hakiem (eds.), Alam Pikiran dan Jejak Perjuangan Prawoto Mangkusasmito: Ketua Umum (Terakbir) Partai Masyumi, Jakarta: Penerbit Buku Kompas, 2014.

Bruinessen, Martin van, "Genealogies of Islamic Radicalism in PostSuharto Indonesia", South East Asia Research, vol. 10, no. 2, 2002, pp. 117-54.

Brumberg, Daniel, "Rhetoric and Strategy, Islamic Movements and Democracy in Middle East", in The Islamism Debate, ed. by Martin S. Kramer, Daniel Brumberg, and Merkaz Dayan le-ḥeker ha-Mizrah ha-Tikhon ỵe-Afriḳah (Universițat Tel-Aviv), Tel Aviv, Israel: Moshe Dayan Center for Middle Eastern and African Studies, 1997.

Connolly, William E., Pluralism, Durham: Duke University Press, 2005.

Dengel, Holk H., Darul Islam dan Kartosuwirjo: Angan-angan yang Gagal, Jakarta: Pustaka Sinar Harapan, 1995.

Departemen Penerangan Republik Indonesia, Kepartaian di Indonesia, Jakarta, 1951.

Dijk, Cornelis Van, Darul Islam: Sebuah Pemberontakan, Jakarta: Grafiti Pers, 1983.

Duverger, Maurice and Robert Wagoner, The Study of Politics, London: Nelson, 1972.

Fealy, Greg, Ijtihad Politik Ulama: Sejarah NU 1952-1967, Yogyakarta: LKIS, 2003. 
Fealy, Greg and Bernhard Platzdasch, "The Masyumi Legacy: Between Islamist Idealism and Political Exigency", Studia Islamika, vol. 12, no. 1, 2005 [http://dx.doi.org/10.15408/sdi.v12i1.646].

Feith, Herbert, The Decline of Constitutional Democracy in Indonesia., Ithaca N.Y.: Cornell University Press, 1968.

----, Pemilihan Umum 1955 di Indonesia, Jakarta: Kepustakaan Populer Gramedia, 1999.

Feith, Herbert and Lance Castles (eds.), Indonesian Political Thinking, 1945 1965, Ithaca: Cornell University Press, 1970.

Firmansyah, Adhe, S.M. Kartosoewirjo: Biografi Singkat, 1907-1962, Yogyakarta: Garasi, 2009.

Fogg, Kevin William, "The Fate of Muslim Nationalism in Independent Indonesia”, Ph.D. Dissertation, New Haven: Yale University, 2012.

Gaus A. F, Ahmad, Sang Pelintas Batas: Biografi Djohan Effendi, Jakarta: ICRP dan Penerbit Buku Kompas, 2009.

Giddens, Anthony, Sociology, Cambridge: Polity Press, 1993.

Gunawan, Hendra, M. Natsir dan Darul Islam: Studi Kasus Aceb dan Sulawesi Selatan Tabun 1953-1958, Jakarta: Media Da'wah, 2000.

Hakiem, Lukman, Perjalanan Mencari Keadilan dan Persatuan: Biografi Dr. Anwar Harjono, S.H., Jakarta: Media Da’wah, 1993.

Hamka, Mubammadiyab-Masyumi, Jakarta: Masyarakat Islam.

Ibrahim, Muchtaruddin, Dr. Sukiman Wirjosandjojo, Hasil Karya dan Pengabdiannya, Jakarta: Departemen Pendidikan dan Kebudayaan, Direktorat Sejarah dan Nilai Tradisional, Proyek Inventarisasi dan Dokumentasi Sejarah Nasional, 1982.

"Interview with Ahmad Syafii Maarif", Asian Christian Review, vol. 2, no. 2\&3, 2008.

Irsyam, Mahrus, Ulama dan Partai Politik: Upaya Mengatasi Krisis, Jakarta: Yayasan Perkhidmatan, 1984.

Jakob Oetama, "Catatan Penutup: Paradoks Eksistensial Prawoto Mangkusasmito", in Alam Pikiran dan Jejak Perjuangan Prawoto Mangkusasmito: Ketua Umum (Terakhir) Partai Masyumi, ed. by S.U. Bajasut and Lukman Hakiem, Jakarta: Penerbit Buku Kompas, 2014. 
Kahin, Audrey, Islam, Nationalism, and Democray: A Political Biography of Mohammad Natsir, Singapore: NUS Press, 2012.

Kahin, George McTurnan, Nationalism and Revolution in Indonesia, Ithaca: Cornell University Press, 1952.

----, “In Memoriam: Mohammad Natsir (1907 -- 1993)", Indonesia, vol. 56, 1993, pp. 158-65.

Kami Memanggil!., Djakarta: Dewan Pimpinan Partai Masjumi, Bahagian Penerangan, 1955.

Legenhausen, Muhammad, "Misgiving about the Religious Pluralisms of Seyyed Hossein Nasr and John Hick", al-Tawbid, vol. 14, no. 3, 1997.

Lucius, Robert E, "A House Divided: The Decline and Fall of Masyumi (1950-1956)", Master's Thesis, Monterey: Naval Postgraduate School, 2003.

Madinier, Rémy, Partai Masjumi: Antara Godaan Demokrasi \& Islam Integral, Bandung: Mizan, 2013.

----, "Berita Masjumi, 24 January, 1952”, in Partai Masjumi: Antara Godaan Demokrasi \& Islam Integral, Bandung: Mizan, 2013.

Madinier, Remy and Andre Feillard Feillard, "At the Sources of Indonesian Political Islam's Failure: The Split between the Nahdlatul Ulama and the Masyumi in Retrospect", Studia Islamika, vol. 6, no. 2, 2014 [http://dx.doi.org/10.15408/sdi.v6i2.729].

Madjid, Nurcholis, "Masyarakat Madani dan Investasi Demokrasi: Tantangan dan Kemungkinan”, Republika, 10 Aug 1999.

Mahendra, Yusril Ihza, Modernisme dan Fundamentalisme dalam Politike Islam: Perbandingan Partai Masyumi (Indonesia) dan Partai Jama'at-i-Islami (Pakistan), Jakarta: Paramadina, 1999.

----, Rekonsiliasi Tanpa Mengkhianati Reformasi: Versi Media Massa, ed. by Andang B. Malla, M. Saleh Mude, and M. Fuad Nashar, Jakarta: Teraju, 2004.

Majid, Nurcholish, "Ikatan Keadaban", in Cendekiawan dan Religiusitas Masyarakat, Jakarta: Tabloid Tekad dan Penerbit Paramadina, 1999.

----, "Jiwa dan Semangat 1945 Masyumi Menolak Suatu 'Machtstaat", in Alam Pikiran dan Jejak Perjuangan Prawoto Mangkusasmito: Ketua Umum (Terakbir) Partai Masyumi, ed. by S.U. Bajasut and Lukman Hakiem, 
Jakarta: Penerbit Kompas, 2014.

----, Masyumi dan Undang-Undang tentang Pendidikan dan Pengajaran di Sekolah, ed. by S.U. Bajasut and Lukman Hakiem, Jakarta: Penerbit Buku Kompas, 2014.

----, "Apakah Ada Manfaatnya Pembentukan MPRS? Karena Haluan Negara toh Sudah ditetapkan", in Alam Pikiran dan Jejak Perjuangan Prawoto Mangkusasmito: Ketua Umum (Terakhir) Partai Masyumi, ed. by S.U. Bajasut and Lukman Hakiem, Jakarta: Penerbit Buku Kompas, 2014.

----, "Pesan Terakhir PP. Masyumi Amanat Umat telah Ditunaikan", in Alam Pikiran dan Jejak Perjuangan Prawoto Mangkusasmito: Ketua Umum (Terakhir) Partai Masyumi, ed. by S.U. Bajasut and Lukman Hakiem, Jakarta: Penerbit Buku Kompas, 2014.

----, "Rugi Untung Perjuangan Harus dinilai dengan Rugi Untungnya Islam", in Alam Pikiran dan Jejak Perjuangan Prawoto Mangkusasmito: Ketua Umum (Terakhir) Partai Masyumi, ed. by S.U. Bajasut and Lukman Hakiem, Jakarta: Penerbit Buku Kompas, 2014.

Mestenhauser, Josef A., "Ideologies in Conflict in Indonesia, 1945-1955.", Ph.D. Dissertation, Minnesota: University of Minnesota, 1960.

Murray, James A.H., William Little, and C.T. Onions, The Shorter Oxford English Dictionary on Historical Principles., Oxford: Clarendon Press, 1964.

Natsir, M., Inilah Chittabku, Djakarta: Penerangan Pimpinan Partai Masjumi, 1953.

----, "Islamic Tolerance", in Indonesian Political Thinking, 1945-1965, ed. by Herbert Feith and Lance Castles, Ithaca: Cornell University Press, 1970.

----, Islam Sebagai Dasar Negara, Jakarta: Dewan Da'wah Islamiyah Indonesia, 2000.

----, Tjita-Tjita Masjumi, Pidato Mohammad Natsir dalam Peringatan Ulang Tabun ke-X Masjumi di Jakarta 1955, Jakarta: KAPU Masjumi Djakarta Raya.

Ngelow, Zakaria J., "Interfaith Cooperation against Radicalism and Violence in Indonesia: A Christian Perspective", CTC Bulletin, vol. 
The View and Attitude of Masyumi towards Pluralism in Politics

24, no. 3, 2008.

Noer, Deliar, Partai Islam di Pentas Nasional: Kisah dan Analisis Perkembangan Politik Indonesia 1945-1965, Bandung: Mizan, 2000.

Oetama, Jacob, "Mohammad Natsir: Jujur dalam Sikap, Santun dalam Tindakan", in 100 Tahun Mohammad Natsir, ed. by Lukman Hakiem, Jakarta: Penerbit Republika, 2008.

"Pertimbangan Madjlis Sjuro Pusat: Sikap Masjumi terhadap Mazhab", Pedoman Perdjuangan Masjumi, $2^{\text {nd }}$ edition, Djakarta: Pimpinan Partai Masjumi, Bagian Keuangan, 1955.

"Program Perdjuangan Masjumi", Pedoman Perdjuangan Masjumi, $2^{\text {nd }}$ edition, Djakarta: Pimpinan Partai Masjumi, Bagian Keuangan, 1955.

"Putusan Madjlis Sjuro Pusat Masjumi tentang Hukum Islam terhadap Komunis", Pedoman Perdjuangan Masjumi, $2^{\text {nd }}$ edition, Djakarta: Pimpinan Partai Masjumi, Bagian Keuangan, 1955.

Rahmah el-Junusijah and Kahrudin Yunus, Djalan Lurus dalam Pendidikan Putera/Puteri, Agama dan Ekonomi, Djakarta: Fikiran Baru, 1956.

Risalah Perundingan Tabun 1957 Sidang ke-III, Konstituante Republik Indonesia, 1957.

Rooney, Kathy, Encarta Concise English Dictionary, Sydney, N.S.W.: Pan Macmillan Australia, 2001.

Rosidi, Ajip, Sjafruddin Prawirangegara Lebih Takut Kepada Allah SWT, Jakarta: Inti Idayu Press, 1986.

Rowe, William L., Philosophy of Religion: An Introduction, $4^{\text {th }}$ edition, California: Wadsworth Cengage Learning, 2007.

Samsuri, "Media Pendidikan Politik Anti-Komunis", in Politik Islam Anti Komunis: Pergumulan Masyumi dan PKI di Arena Demokrasi Liberal, Yogyakarta: Safiria Insania Press bekerjasama dengan Magister Studi Islam, Universitas Islam Indonesia, 2004.

Sanchez-Cuenca, Ignacio, “Party Moderation and Politicians' Ideological Rigidity", Party Politics, vol. 10, no. 3, 2004, pp. 325-42 [http:/ /dx.doi. org/10.1177/1354068804039120].

Scruton, Roger, A Dictionary of Political Thought, London: Pan Book, 1983. Suhelmi, Ahmad, Soekarno versus Natsir: Kemenangan Barisan Megawati, 
Reinkarnasi Nasionalis Sekuler, Jakarta: Darul Falah, 1999.

“Tafsir Asas", Pedoman Perdjuangan Masjumi, $2^{\text {nd }}$ edition, Djakarta:

Pimpinan Partai Masjumi, Bagian Keuangan, 1955.

Thoha, Anis Malik, Tren Pluralisme Agama: Tinjauan Kritis, Jakarta: Perspektif, 2005.

Timu, Chris S.K., "Natsir, Aspirasi Islam dan Komunitas Katolik", in 100 Tahun Mohammad Natsir, ed. by Lukman Hakiem, Jakarta: Penerbit Republika, 2008.

Wiryosukarto, Amir Hamzah (ed.), Wawasan Politik Seorang Muslim Patriot: Kumpulan Karangan, Jakarta: YP2LPM (Yayasan Pusat Pengkajian, Latihan, dan Pengembangan Masyarakat), 1984.

Wissenburg, M.L.J., Political Pluralism and the State: Beyond Sovereignty, New York: Routledge, 2009.

Wolf, Charles, The Indonesian Story; The Birth, Growth and Structure of the Indonesian Republic., New York: Institute of Pacific Relation, 1949. 